\title{
In vitro embryo rescue of interspecific hybrids of oil palm (Elaeis oleifera $x$ Elaeis guineensis)
}

\author{
Sergio Augusto Oliveira Alves ${ }^{1 *}$, Oriel Filgueira de Lemos ${ }^{2}$, Benedito Gomes dos Santos \\ Filho $^{3}$ and André Luís Lopes da Silva ${ }^{4}$
}

${ }^{I}$ Departamento de Ciências florestais e Laboratório de Recursos Genéticos e Biotecnologia; Escola Superior de Agricultura Luiz de Queiroz - ESALQ/USP; 13418-900; Piracicaba - SP - Brasil. ${ }^{2}$ Embrapa Amazônia Oriental ,Pavilhão de Pesquisa; 66095-100 ; Belém - PA - Brasil. ${ }^{3}$ Universidade Federal Rural da Amazônia -UFRa ;Departamento de Fisiologia Vegetal; 66077-901; Belém - PA - Brasil. ${ }^{4}$ Departamento de Engenharia de Bioprocessos e Biotecnologia; Universidade Federal do Paraná; 81531-970; Curitiba - PR - Brasil.

\begin{abstract}
The oil palm (Elaeis guineennsis Jacq.) is the plant with major oil yield in tropical areas over the world. Pará state is the major producer of Brazil. However, the production of resistant hybrids (Elaeis oleifera $x$ Elaeis guinennsis) to several diseases is necessary, in spite of less productive, is a viable alternative for areas where occur more aggressive diseases. The aim of this research was to rescue in vitro embryos of four varieties of interspecific hybrids of oil palm (Elaeis oleifera x Elaeis guineensis) in different media. Four varieties were tested: (1) Cj-2141; (2) CI2061; (3) Cj-502 and (4) Cj-494. Four media were tested: (T1) half strength MS medium (1/2 MS), (T2) MS, (T3) MS $+0.5 m^{-1} L^{-n a p h t h a l e n e a c e t i c ~ a c i d ~(N A A) ~ a n d ~ 6-b e n z y l a m i n o p u r i n e ~(B A P) ~ a n d ~(T 4) ~ 1 / 2 ~ M S+~ 0.5 m g . ~} L^{-1}$ NAA and BAP. All media were supplemented with $0.17 \mathrm{~g} . \mathrm{L}^{-1} \mathrm{NaH}_{2} \mathrm{PO}_{4}$, activated charcoal $(0.25 \%)$, sucrose $(3 \%)$ and solidified with phytagel $(0.2 \%)$. The most germination rate of interspecific hybrids embryos was obtained on $1 / 2$ MS medium, supplemented with 0.17g. $\mathrm{L}^{-1} \mathrm{NaH}_{2} \mathrm{PO}_{4}$, activated charcoal (0.25\%), sucrose (3\%) and solidified with phytagel (0.2\%). The variety CI-2061 presents the best capacity to develop normal seedlings.
\end{abstract}

Key words: Vegetable oil, zygotic embryos, genetic breeding

\section{INTRODUCTION}

The oil palm (Elaeis guineensis Jacq.) belongs to Arecaceae family and is originated from West Africa. It is the major source of vegetable oil in the world and the first plant used in the production of vegetable oil commercialized in the international market (Carvalho et al., 2006). The genus Elaeis presents two species of genetic interesting: The caiaué (Elaeis oleifera (HBK) Cortés) and the African species (Elaeis guineensis Jacq.) (Surre and Ziller, 1969; Viégas and Muller, 2000). The oil palm is a tropical species that grows mainly in hot climate and humid with abundance of rains. The North region of Brazil shows the ideal conditions for the growth of oil palm.

The Brazil has high agricultural potential for oil palm plantation with ca. 50 million hectares, being 30 million in the Amazonas State and the others 20 million in the Pará State (Carvalho et al., 2006). Nowadays, the Pará State is the major producer of oil palm in the Brazil. The main species used in the commercial plantation is the Elaeis guineennsis, nevertheless, this species is susceptible to several diseases, such as fatal yellowing disease (Alves, 2007); the fatal yellowing disease represents the largest menace to the oil palm production in Pará. However, Elaeis oleifera has been incorporated in genetic breeding of oil palm, in spite of being less productive than E. guineennsis, this species presents other interesting characteristics, such as high quality in the oil, slow growth of the stem and resistance or tolerance to some diseases, mainly against fatal yellowing disease.

The oil palm is a monocotyledon and perennial palm with long cycle of production around 25 years, which results in a slow process of conventional genetic breeding (Alves, 2007). Innovative methods are necessary to reach the incorporation of new genetic resources inside the new cultivars of oil palm. The tissue culture is a powerful tool that can accelerate the genetic breeding of the species. The use of interspecific hybrids such as E.oleifera $\mathrm{x}$ E.guineensis can

Author for correspondence: sergioagrobio@ig.com.br

J. Biotec. Biodivers. v. 2, N.2: pp. 1-6, May. 2011 
overcome the problem caused by fatal yellowing disease. However, crosses between Elaeis oleifera $\mathrm{x}$ Elaeis guineensis can produce seeds with embryos that present pre and post-zygotic barriers, resulting in seeds with abortive embryos. On the other hand, these hybrid embryos can be rescued if were removed before that the abort can occur and these hybrid embryos must be cultivated in vitro to develop a complete plant (Asano and Imagawa, 1999; Alves, 2007).

The aim of this research was to rescue in vitro embryos of four varieties of interspecific hybrids of oil palm (Elaeis oleifera $x$ Elaeis guineensis) in different media.

\section{MATERIAL AND METHODS}

This research was carried out at laboratory of Biotechnology and Genetic Resources of Embrapa Amazônia Oriental, Belém, Pará, Brazil.

\section{Culture of oil palm embryos Plant Material}

The embryos from hybrid seeds of oil palm used in this experiment were originated from the Embrapa Amazônia Ocidental germplasm bank, Amazonas, Brazil. It was used four varieties: (1) $\mathrm{Cj}-2141$; (2) CI-2061; (3) Cj-502 and (4) Cj-494. These varieties were chosen in agreement with the performance in the field, as high production of bunches and oil. All the embryos were originated from crosses (E. oleifera x E. guineensis).

\section{Disinfection}

The seeds were washed with distilled and sterile water for five times until do not exist any type of visible dirt. After this washing, the seeds were placed in a laminar air flow chamber followed by immersion in $70 \%$ alcohol for 2 minutes and after, the seeds were immerged in a sodium hypochlorite solution $1 \%(\mathrm{NaClO})$ for 20 minutes, and after the embryos were washed for four times with distilled and sterile water. After the disinfection the embryos were removed from seeds and inoculated on the regeneration medium.

\section{Regeneration culture medium}

In order to select the best culture medium to regeneration of embryos, four varieties were cultured in following treatments: (T1) half strength MS medium ( $1 / 2$ MS) (Murashige and Skoog, 1962), (T2) MS, (T3) MS + 0.5mg L $\mathrm{L}^{-1} 1-$ naphthaleneacetic acid (NAA) and 6- benzylaminopurine (BAP) and (T4) $1 / 2 \mathrm{MS}+$ $0.5 \mathrm{mg} . \mathrm{L}^{-1}$ NAA and BAP. All media were supplemented with 0.17 g. $\mathrm{L}^{-1} \mathrm{NaH}_{2} \mathrm{PO}_{4}$, activated charcoal $(0.25 \%)$, sucrose $(3 \%)$ and solidified with phytagel $(0.2 \%)$.

The $\mathrm{pH}$ was adjusted to 5.8 before phytagel to be added. The media were autoclaved at $121^{\circ} \mathrm{C}$ for 15 min. The embryos were excised from the seeds and it was inoculated in flasks of $300 \mathrm{ml}$ with 50 $\mathrm{ml}$ culture medium. The embryos were cultivated for eight weeks. In the first week, the embryos were cultivated in the dark. The evaluation was made through scores. It was attributed one score to each answer of embryo. This score varied from 0 to 6 (Figure 1). The description of score is: Zero (0) - attributed to embryos without development; One (1) -for embryos that was observed swelling; Two (2) for embryos that obtained curvature beginning; Three (3) for embryos partially curved; Four (4) for embryo completely curve; Five (5) for embryo with beginning of shoot and root development; and Six (6) for embryos with aerial part and root developed.

It was considered as the best treatment those that show the high percentage of score six during the period of 60 days of culture.

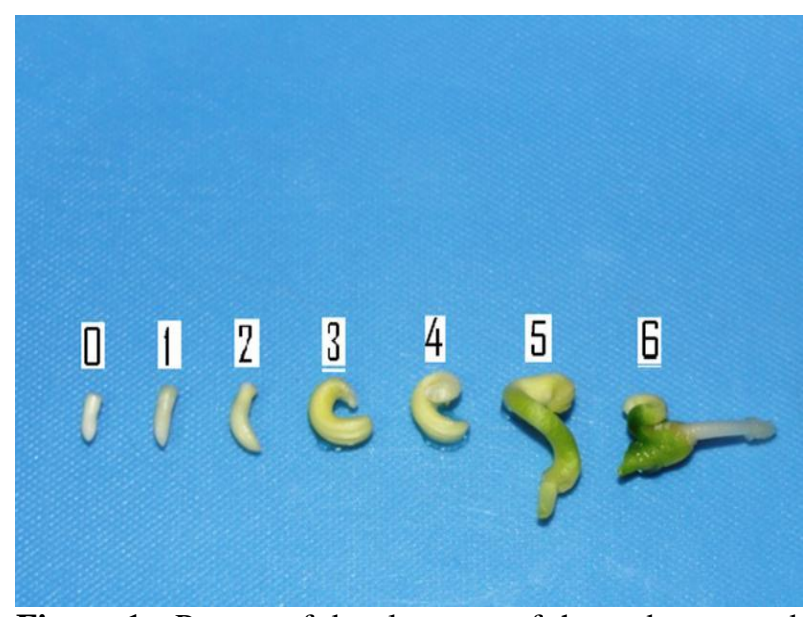

Figure 1 - Pattern of development of the embryos used to determine the evaluation score (range from 0 to 6).

\section{RESULTS}

After the first week of culture, it was observed just swelling of zygotic embryos (Figure 2A). From 17 to 21 days it was observed the curvature process of embryo (Figure 2B). Beginning of the root and aerial part of seedling was observed at 30 days of culture (Figure 3C). After 40 days, the differentiation was too clear with formation of expanded cotyledon, root and leaves (figure 2D). 
In previous experiment, we observed that the supplementation with $0.17 \mathrm{~g} . \mathrm{L}^{-1} \quad \mathrm{NaH}_{2} \mathrm{PO}_{4}$ was indispensable for the obtaining normal plantlets (Data not shown).

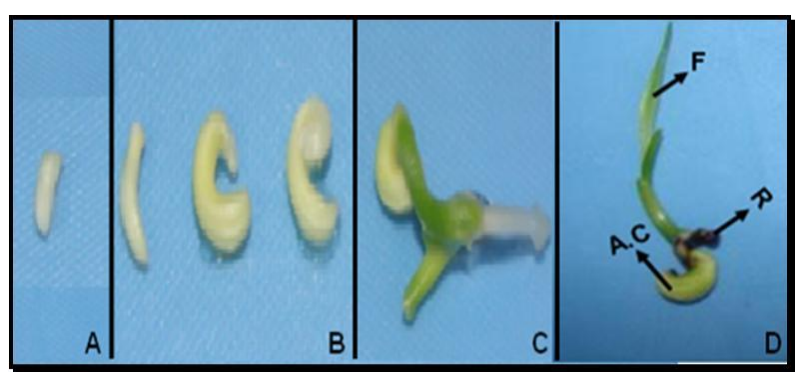

Figure 2 - In vitro conversion of zygotic embryos to plantlets of oil palm from variety CI-2061. (A) Swelling embryos. (B) Curvature process of embryo. (C) Beginning of the root and aerial part of seedling and (D-F) Leave formation, (D-A.C) cotyledons and (D-R) Roots.

Embryos cultured on the $1 / 2$ MS medium free of plant growth regulators (T1 treatment) presented the higher percentage of score 6 with $57.9 \%$, being $20 \%$ to variety $\mathrm{Cj}-2141$ and $37.93 \%$ to variety CI2061 (Figure 3). The varieties $\mathrm{Cj}-502$ and $\mathrm{Cj}-594$ obtained inferior development, they did not reach score 6 (Figure 3).

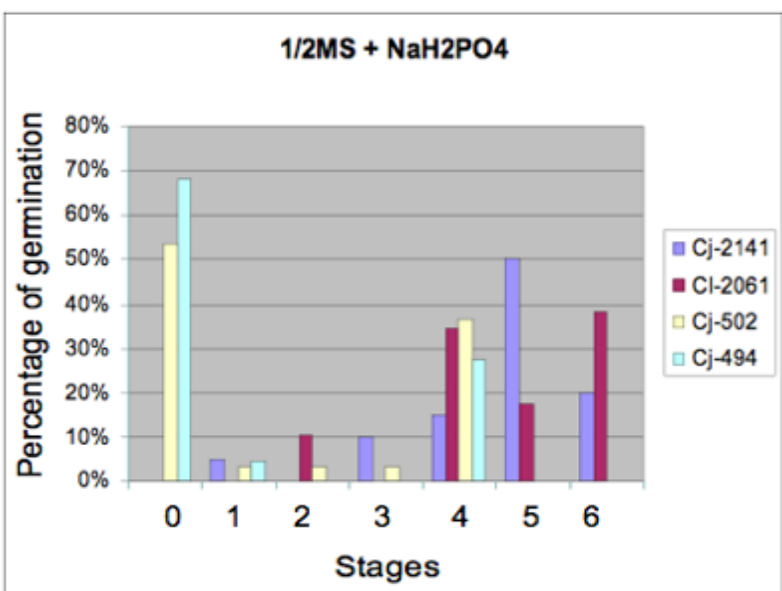

Figure 3 - Percentage of in vitro germination of embryos of the four varieties of interspecific hybrids of oil palm (Elaeis oleifera $\mathrm{x}$ Elaeis guineensis) on $1 / 2 \mathrm{MS}$ medium (T1). Stages are represented by scores (Figure 1). Values obtained at 60 days of culture.

In the treatment T4, 1/2 MS medium supplemented with $0.5 \mathrm{mg} . \mathrm{L}^{-1} \mathrm{BAP}$ and NAA, it was obtained $51.03 \%$ of embryos with score 6 , being $20 \%$ to variety $\mathrm{Cj}-2141$ and $31 \%$ to variety $\mathrm{CI}-2061$. The varieties $\mathrm{Cj}-502$ and $\mathrm{Cj}-594$ show inferior development, they did not reach score 6 (Figure $4)$.

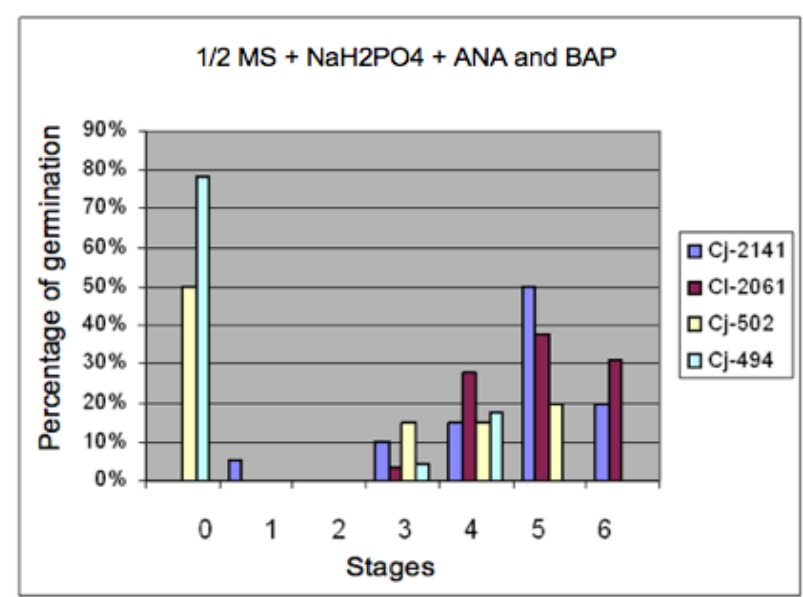

Figure 4 - Percentage of in vitro germination of embryos of the four varieties of interspecific hybrids of oil palm (Elaeis oleifera $\mathrm{x}$ Elaeis guineensis) on $1 / 2 \mathrm{MS}$ medium $+0.5 \mathrm{mg} \mathrm{L}^{-1} \mathrm{NAA}$ and BAP (T4). Stages are represented by scores (Figure 1). Values obtained at 60 days of culture.

In the T2 treatment, MS medium free of plant growth regulators, the percentage of score six varied from 0 to $37.93 \%$ (Figure 5). The variety that presented higher percentage of score 6 were the $\mathrm{Cj}-2141$ with $37.93 \%$, followed by $\mathrm{Cj}-2141$ with $20 \%$ of score 6 . However, the varieties $\mathrm{Cj}$ 502 and $\mathrm{Cj}-494$ did not reach score 6 (Figure 4).

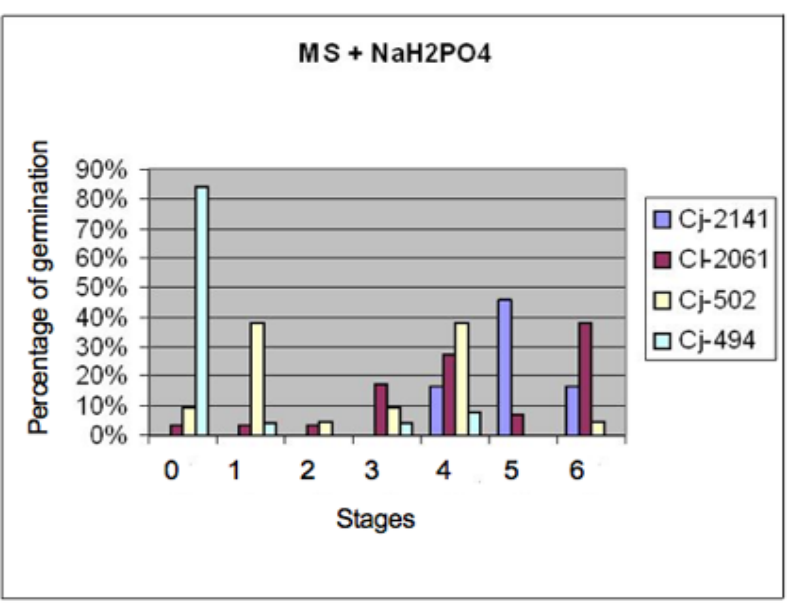

Figure 5 - Percentage of in vitro germination of embryos of the four varieties of interspecific hybrids of oil palm (Elaeis oleifera x Elaeis guineensis) on MS medium (T2). Stages are represented by scores (Figure 1). Values obtained at 60 days of culture.

In the treatment T3, MS medium supplemented with BAP and NAA, the percentages of score 6 obtained were lower, nevertheless, the varieties 
CI-2061 and Cj-2141 presented $20 \%$ and $6.6 \%$ of score 6 , respectively. The others two varieties did not present score 6 (Figure 6).

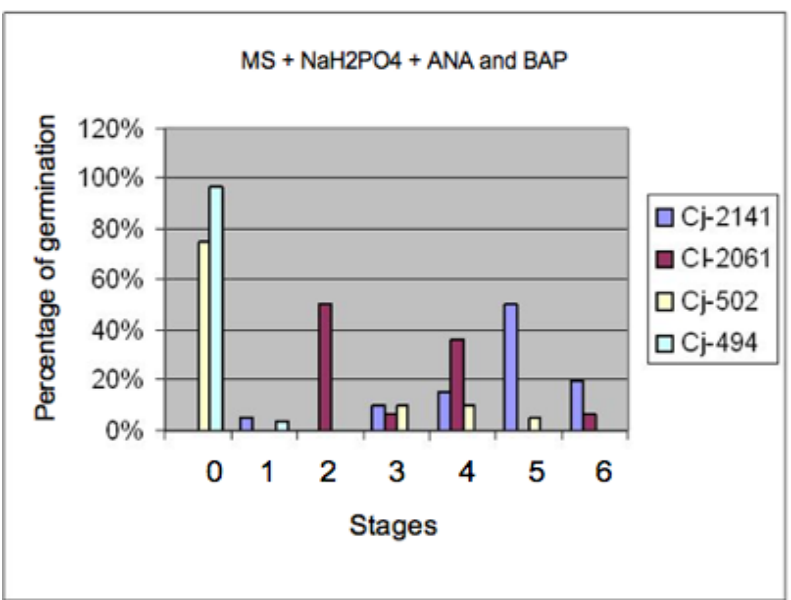

Figure 6 - Percentage of in vitro germination of embryos of the four varieties of interspecific hybrids of oil palm (Elaeis oleifera $\mathrm{x}$ Elaeis guineensis) on MS medium $+0.5 \mathrm{mg} \mathrm{L}^{-1} \mathrm{NAA}$ and BAP (T3). Stages are represented by scores (Figure 1). Values obtained at 60 days of culture.

The presence of plant growth regulator on the MS medium decreases the efficiency of conversion of embryos to the score 6 . The behaviour of embryos was similar on the MS and $1 / 2$ MS medium.

\section{DISCUSSION}

During the experiments, the varieties CI-2061 and Cj-2141 obtained the best results on MS medium and $1 / 2$ MS and these results did not depend on the presence or absence of plant growth regulators. However, the other two varieties $\mathrm{Cj}-502$ and $\mathrm{Cj}$ 494 did not present good results independently of culture medium. Different varieties of rice submitted to the same medium also obtained different answers of regeneration from embryogenic callus (Khatun et al., 2003; Islam et al., 2004). The different answers observed among varieties reflect genotype-dependent.

Although, these varieties have the same origin ( $E$. oleifera $\times$ E. guineensis) they are different and when submitted to the same medium, it is possible to determine the genetic superiority of several varieties. The genetic superiority of the variety to one determined characteristic can be revealed when this variety is cultivated in some nutritive medium with different combinations of plant growth regulators (Fantini Junior and Graça, 1990; Alves, 2007). The tissue culture is an important tool for genetic breeding to the identification of genotypes that show high stability (i.e. genotypes that have high adaptability in general, to be able to produce very well in the different conditions of the environment) (Cruz and Regazzi, 2001).

The embryos cultivated on the MS and $1 / 2$ MS medium, both supplemented with $0.5 \mathrm{mg} . \mathrm{L}^{-1} \mathrm{BAP}$ and NAA obtained inferior results when it compared with those cultured on medium free of these regulators. This inhibitory action of plant growth regulators $\left(0.5 \mathrm{mg}\right.$. $\mathrm{L}^{-1} \mathrm{BAP}$ and NAA) can indicate that embryos are in mature or cotyledonary stage because in this phase it synthesizes endogenous hormones that are need to complete development (Lemos, 2003; Alves, 2007).

Moreover, the presence of charcoal activated in culture medium can had decreased the action of plant growth regulators (Teixeira et al., 1993; Alves, 2007). The charcoal activated promotes the adsorption of several substances such as plant growth regulators. It is possible that the increase of the levels of growth regulators could result in some effect.

During the conversion process of zygotic embryos in seedlings of açaí palm (Euterpe oleracea Mart.) cultured on MS medium with $0.25 \%$ charcoal activated also it was verified no effect of growth regulators at the formation process of seedlings from zygotic embryos (Cavalcante, 2001). On the other hand, the formation of oil palm seedlings in MS medium, it was verified the need of include $2.5 \mathrm{mg} . \mathrm{L}^{-}$ ${ }^{1} 2.4$ - D for the suitable formation of the plants, using culture medium free of charcoal activated (Kanchanapoom and Domyoas, 1999).

Different results were observed in the formation of seedlings of coconut palm (Cocos nucifera L.) which was obtained complete plants after 75 days using MS medium with $0.1 \mathrm{mg} . \mathrm{L}^{-1} \mathrm{NAA}$ and BAP (Silva, 2002).

After 60 days from the inoculation of embryos in MS or $1 / 2$ MS medium, the varieties CI-2061 and $\mathrm{Cj}$-2141 formed seedlings with leaves and roots (Figure 7). In Euterpe oleracea, seedlings were obtained at 30 days of culture in MS medium in the absence of growth regulators (Cavalcante, 2001). 


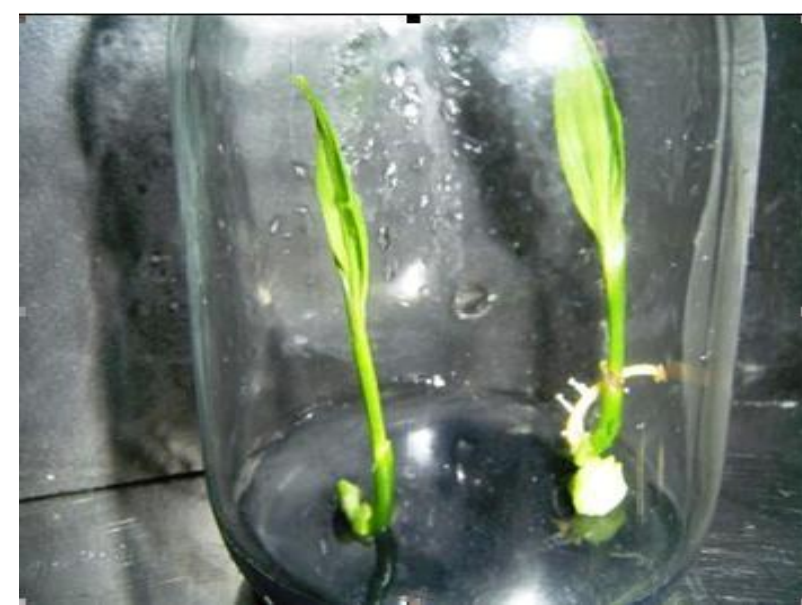

Figure 7 - Aspect of the complete plant formed from embryos rescued and cultured in vitro after two months.

\section{CONCLUSIONS}

The most germination rate of interspecific hybrids embryos was obtained on $1 / 2$ MS medium, supplemented with $0.17 \mathrm{~g} . \mathrm{L}^{-1} \mathrm{NaH}_{2} \mathrm{PO}_{4}$, activated charcoal $(0.25 \%)$, sucrose (3\%) and solidified with phytagel $(0.2 \%)$. The variety CI-2061 presents the best capacity to develop normal seedlings.

\section{RESUMO}

O Dendezeiro (Elaeis guineennsis Jacq.) é a oleaginosa com a maior produtividade por hectare em áreas tropicais do mundo. O estado do Pará é o maior produtor nacional. Entretanto, é necessário a produção de híbridos (Elaeis oleifera x Elaeis guineennsis) resistentes a varias doenças encontrada na área de plantio. O objetivo dessa pesquisa foi resgatar embriões de quatro variedades de híbridos interespecíficos do dendezeiro (Elaeis oleifera x Elaeis guineennsis) em diferentes meios de cultura. As seguintes variedades (CI-2061, Cj-2141, Cj-502 e Cj-492) e os meios de cultura: (1) $1 / 2 \mathrm{MS}$, (2) MS, (3) MS + 0,5 mg.. $\mathrm{L}^{-1} \mathrm{de}$ ácido naftalenoacético (ANA) e 6-benzilaminopurina (BAP) e (4) 1/2 MS + 0,5 mg. $\mathrm{L}^{-1}$ de ANA e BAP foram testados. Todos os meios de cultura foram suplementados com 0,17 g.. ${ }^{-1}$ de $\mathrm{NaH}_{2} \mathrm{PO}_{4}, 0,25 \%$ de carvão ativado, $3 \%$ de sacarose e solidificado com $0,2 \%$ de phytagel. A maior taxa de germinação dos embriões de híbridos interespecíficos foi obtida no meio $1 / 2 \mathrm{MS}$ suplementado com 0,17 g. $\mathrm{L}^{-1}$ de $\mathrm{NaH}_{2} \mathrm{PO}_{4}, 0,25 \%$ de carvão ativado, $3 \%$ de sacarose e solidificado com $0,2 \%$ de phytagel. A variedade CI-2061 apresentou maior capacidade de desenvolver plântulas normais.

Palavras-chave: Óleo vegetal, embrião zigótico, melhoramento genético

\section{REFERENCES}

Alves, S. A. O. Regaste de híbridos interespecíficos de dendezeiro (Elaeis oleifera $\mathrm{x}$
Elaeis guineensis). Dissertação (Mestrado em Botânica) - Universidade Federal Rural da Amazônia/Museu Paráense Emilio Goeldi, 2007.

Asano, Y.; Imagawa, M. (1999), Hybrid seed formation among Dioscorea opposita Thunb. cvs. Nagaimo, Ichoimo, Tsukuneimo and Dioscorea japonica Thunb. Journal of the Japanese Society for Horticultural Science, 68, 591-597.

Cavalcante, A. S. L. Respostas morfogenéticas in vitro de açaizeiro (Euterpe oleracea L.) e de cupuçuazeiro (Theobrama grandiflorum (Wild. Ex Spreng) Schum). Tese (Doutorado em Fitotecnia) Universidade Federal do Ceará, 2001.

Carvalho, A. V.; Alves, B. J. R.; Reis, V. M. (2006), Resposta do dendezeiro à adição de nitrogênio e sua influência na população de bactérias diazotróficas. Pesquisa Agropecuaraia. Brasileira, 41, 293-300.

Cruz, C. D.; Regazzi, A. J. (2001), Modelos biométricos aplicados ao melhoramento genético. $2^{\mathrm{a}}$. Ed. Viçosa: Universidade Federal de Viçosa, 390p.

Fantini Junior, M. and Graça, M. E. C. Propagação in vitro de Eucalyptus saligna (1990), In: Congresso Florestal Brasileiro. Anais: São Paulo: Sociedade Brasileira de Silvicultura, 373-378p.

Islam, M. M.; Wahed, S. A.; Khan, S. A. K. U. (2004), Studies on callus induction and regeneration from dehulled rice (Oryza sativa L.) seeds. Plant Tissue Culture and Biotechnology, 14, 155-160.

Khatun, M. M.; Ali M. H.; Desamero, N. V. (2003), Effect of genotype and culture media on callus formation and plant regeneration from mature seed scutella culture in rice. Plant Tissue Culture and Biotechnology, 13, 99-107.

Kanchanapoom, K.; Domyoas; P. (1999), The Origin and Development of Embryoids in Oil Palm (Elaeis guineensis Jacq.) Embryo Culture. Science Asia, 25, 195-202.

Lemos, O. F. P. Mutagênese e tecnologia in vitro no melhoramento genético de pimenta-do-reino (Piper nigrum L.). Tese (Doutorado em 
Agronomia). Escola Superior de Agricultura "Luiz de Queiroz”, Universidade de São Paulo, 2003.

Murashige, T. and Skoog, F. (1962), Revised medium for rapid growth and bioassays with tobacco tissue culture. Physiologia Plantarum, 15, 473-497.

Silva, V. S. Regeneração in vitro de embriões de Cocos nucifera L. Dissertação (Mestrado em Ciências). Escola Superior de Agricultura "Luiz de Queiroz”, Universidade de São Paulo, 2002.
Surre, C.; Ziller, R. (1969), La palmera de aceite. Barcelona: Ed. Blume (Coleccion Agricultura Tropical), 231p.

Teixeira, J. B.; Söndahl, M. R.; Kirby, E. G. (1993), Somatic embryogenesis from immature zygotic embryos of oil palm. Plant Cell Tissue and Organ Culture, 34, 227-233.

Viegas, I. de J. M. and Muller, A. A. (2000), A cultura do dendezeiro na Amazônia brasileira. Belém: Embrapa-Cpatu; Manaus: EmbrapaCPAA, 374p. 